\author{
Dr. sc. Mladen Pavlović, znanstveni suradnik* \\ Split
}

\title{
ZNAČAJ MATERIJALNOPRAVNIH SASTAVNICA U SUDSKOM SPORU
}

\author{
$U D K: 347.9$ \\ Primljeno: 5. 10. 2017. \\ Pregledni rad
}

Pravnim subjektima se dispozicijama pravnih normi daju ovlaštenja, nalažu dužnosti i odgovornosti ili izriču zabrane određenog ponašanja kada nastanu hipotezom predviđene činjenice iz tih pravnih normi. Subjektivna prava i dužnosti određenog ponašanja nalaze svoja pravna uporišta ili osnovu u materijalnim pravnim normama građanskog javnog i privatnog prava.

Da bi nastao određeni građanskopravni odnos sa subjektivnim pravima i obvezama za određene subjekte nije dovoljna sama pravna osnova, već je potrebno da se ostvare i sve činjenice koje se materijalnopravnom normom traže kao pretpostavke za njegov nastanak, promjenu ili prestanak.

U uzročnom kompleksu nastanka ili promjeni svakog građanskopravnog odnosa uvijek se nalaze pravna i činjenična osnova. Stoga i utvrđivanje postojanja konkretnog subjektivnog građanskog prava i obveza podrazumijeva obvezno dokazivanje njegove pravne i činjenične osnove.

Odlučivanje o meritumu spora, odnosno o osnovanosti ili neosnovanosti tužbenog zahtjeva ukazuje se kao jedan od najtežih zadataka za sve njegove sudionike jer bi pri tome svaki za sebe morali pravilno i zakonito ocijeniti utjecaj svih pravnih čimbenika, odnosno sastavnica na rezultate sudskog spora. Te sastavnice, odnosno čimbenici, u ovom se članku razmatraju prvenstveno s aspekta građanskog materijalnog prava s naglaskom na njegovu ulogu u tretiranju građanskopravnog i sudskog spora, pravne osnove tužbenog zahtjeva, materijalnopravne i činjenične osnove spora te njegove uloge na sporni građanskopravni odnos stranaka.

Ključne riječi: građanskopravni spor, sudski spor, tužbeni zahtjev, pravna osnova, činjenična osnova, subjektivno pravo

\section{UVODNE NAPOMENE}

Ostvarivanje pravne zaštite $u$ građanskom parničnom postupku otvara nam problem odnosa pravnih pravila kojima se regulira procesna djelatnost suda, stranaka i ostalih sudionika u postupku prema normama građanskog materijalnog i procesnog prava. Odnos građanskog i ostalih privatnih prava s jedne strane i građanskog procenog prava s druge, vrlo je složen, pa ne čudi što je taj odnos bio predmetom različitih motrišta i prijepora u znanstvenoj i stručnoj literaturi. Takvo stanje

*Dr. sc. Mladen Pavlović, znanstveni suradnik, 21000 Split, Domovinskog rata, mladen.pavlovic39@ gmail.com 
odrazilo se na zakonodavstvo i sudsku praksu, jer je bilo nekih autora prema kojima je građansko procesno pravo smatrano samo dijelom građanskog privatnog prava te onih prema kojima je to pravo od građanskog prava potpuno odvojeno i neovisno. ${ }^{1}$ Takva suprotna poimanja pokazala su se neprihvatljivima, jer nisu dovoljno vodila računa o ulozi koju je pravni poredak glede privatnih građanskopravnih odnosa pojedinaca namijenio građanskom pravosuđu. Stoga je s vremenom prevladalo shvaćanje da su građansko materijalno i građansko procesno pravo dva samostalna dijela pravnog poretka, ali i da među njima ipak postoji dijalektička sinteza koja proizlazi iz normi jednog i drugog područja prava kao zajedničkog ishodišta koje se nalazi u društvenim odnosima. Ti se odnosi na specifičan način reguliraju pravilima građanskog materijalnog i procesnog prava. Kod toga građanskopravna ovlaštenja prema partneru iz određenog građanskopravnog odnosa nalaze svoj izvor u onome istom društvenom odnosu iz kojeg proistječe i zahtjev za ostvarivanje pravne zaštite u građanskom sudskom postupku. Na taj način građanskopravna i procesnopravna ovlaštenja predstavljaju lice i naličje jednog te istog društvenog fenomena. ${ }^{2}$

Uloga materijalnog građanskog prava $^{3}$ u pravnom sustavu jest uređivanje pravnim normama u društvu međusobnih odnosa slobodnih i ravnopravnih pojedinaca, odnosno njihovih građanskopravnih odnosa. Ono na taj način uspostavlja pravni kauzalitet u pogledu kojeg nastaju građanskopravni učinci, koji se ogledaju u postanku (osnivanju), mijenjanju i prestanku subjektivnih građanskih (privatnih) prava $^{4}$ i obveza ${ }^{5}$ pojedinaca $u$ njihovim međusobnim pravnim odnosima. Takvo materijalno građansko pravo, koje je izgrađeno na ustavnim načelima slobode i ravnopravnosti svih građana, omogućuje da pod jednakim pretpostavkama koje određuju norme građanskog privatnog prava stječu i imaju subjektivna građanska prava, da izvršavaju njihov sadržaj, da s njima slobodno raspolažu i do potrebe da ih štite od tuđih protupravnih postupaka. Za ostvarenje tih ciljeva često će biti potrebna

1 Siniša Triva i Mihajlo Dika, Građansko parnično procesno pravo, Narodne novine, Zagreb 2004., parag.3., str. 11-13 (u daljnjem tekstu: Triva - Dika, o. c.).

2 Triva - Dika, Ibid. Prema Općoj hrvatskoj enciklopediji, fenomen u proširenom smislu riječi znači neku iznimnu pojavu.

Materijalno (supstancijalno) pravo naziv je kojim se u zakonskim i drugim tekstovima, a posebno onima koji se odnose na sudski postupak, naziva ono pravo koje nije procesnopravne naravi. Tako prof. em. Nikola Gavella u svojem izvornom znanstvenom radu „O odnosu materijalnog i procesnog građanskog prava u parnicama - Pogled sa stajališta privatnog (građanskog) prava“, Zbornik radova PFZ, br. 63 /2013., str. 537-567 (u daljnjem tekastu: Gavella, N., o. c.) opravdano upozorava u svojoj prvoj bilješci da se time naziva materijalnim nešto što je tako nematerijalno kao što su to pravne norme čemu bi se opravdano moglo prigovoriti. Međutim, da se naziv materijalno pravo već duboko ukorijenio te se njime naglašava razlika prema procesnom (postupkovnom) pravu o kojemu se nekada govorilo kao o formalnom pravu, ali se u pogledu ostalog neprocesnog prava zadržao naziv materijalno pravo. Napominjemo da Gavellin rad, s obzirom na svoj izvorni značaj i važnost za praksu, predstavlja pratitelja u našem daljnjem izlaganju.

Pod nazivom subjektivno građansko pravo, odnosno subjektivno privatno pravo razumijeva se pravna vlast koja u građanskopravnom odnosu pravno pripada pojedinom pravnom subjektu, a proizlazi iz normi objektivnog građanskog privatnog prava. Kolika i kakva pravna vlast pripada pojedincu, ovisit će o pravnoj naravi i sadržaju njegovog subjektivnog prava, a u pogledu čega se odnosi, ovisit će o objektu (predmetu) tog njegovog prava.

Obveze same po sebi nisu zasebni element građanskopravnih odnosa, nego u njima naličje tuđih subjektivnih prava. 
pomoć javne vlasti (suda). Objektivne pravne norme i subjektivna prava koja iz njih proistječu postoje u nematerijalnom svijetu s nakanom da u stvarnosti među pojedincima proizvode određene pravne učinke. Često se to dragovoljno ne postiže, radi čega je potrebna pomoć suda, da bi se ostvarila ili zaštitila subjektivna prava pojedinca zasnovana na objektivnom pravu. U pravno uređenim društvima, kakvo je i naše, uspostavljeni su pravosudni mehanizmi kojima je stavljeno u dužnost omogućiti i pomagati svakome u ostvarivanju i zaštiti njegovih subjektivnih prava. ${ }^{6}$

Svatko ima pravozaštitni zahtjev ${ }^{7}$ za pružanje pravne zaštite određenog sadržaja u stvarnoj pravnoj situaciji, koji se odražava kao konkretno ostvarivanje općeg prava na tužbu. Stoga svaki nositelj subjektivnog građanskog prava koji bi trebao ostvariti zaštitu u odnosu na nekog drugog, pa i onaj koji samo tvrdi ili smatra da je nositelj takvog prava, ovlašten je od suda zahtijevati poduzimanje propisanih procesnih aktivnosti. Sud je nedvojbeno dužan djelovati u skladu s materijalnim pravom, a prema pravilima građanskog procesnog prava. ${ }^{8}$ Potonjim normama propisan je način kako sudovi obavljaju svoju funkciju te organizacijsko i funkcionalno njihovo djelovanje. Zbog navedene uloge građanskog procesnog prava isto se susreće s građanskim pravom na određenoj razini na kojoj zajedno teže donošenju zakonitih meritornih odluka u svim onim slučajevima koji su predmetom sudskog postupanja, a koji se doista nezgrapno nazivaju građanskopravnim stvarima. ${ }^{9} \mathrm{U}$ tome građansko materijalno i građansko procesno pravo surađuju onako kako zahtijevaju i omogućuju njihove uloge u pravnom sustavu. Iako svako od njih ima vlastito područje djelovanja, vlastite metode i vlastitu različitu pravnu prirodu, $\mathrm{u}$ situacijama kada im se područja djelovanja podudaraju, građansko materijalno i građansko procesno pravo zaista djeluju u svojevrsnoj simbiozi. ${ }^{10}$

6 Prema odredbi čl. 46. st. 1. Ustava Republike Hrvatske (NN 56/90,135/97,8/98, 113/00, 124/00,28/01,41701,55/01, 76/10, 85/10,5/14), svatko ima pravo da zakonom ustanovljeni neovisni i nepristrani sud pravično i u razumnom roku odluči o njegovim pravima i obvezama, ili o sumnji ili optužbi zbog kažnjivog djela.

Triva - Dika, o. c., par. 4, str. 18-24, te Gavella, N., o. c., str. 541. i bilješke pod 12 i 13., prema kojima pravni poredak omogućuje svakome da preko javne vlasti (suda) ostvaruje onu privatnopravnu vlast (ovlaštenje) koja mu u društvu pripada kao nositelju konkretnog subjektivnog građanskog prava i da štiti to svoje pravo od tuđih protupravnih smetanja i zadiranja. To se omogućuje u pravilu preko sudova, a samo ako je to određeno posebnim propisom, preko drugih tijela vlasti, odnosno osoba kojima su dane neke javne ovlasti (kao npr. javnim bilježnicima u ostavinskom i ovršnom postupku, izmiriteljima u postupku mirenja). U slučajevima kada o subjektivnim građanskim pravima odlučuju tijela upravne vlasti ili druga tijela vlasti ili pak osobe koje imaju javne ovlasti, suvremeni pravni poreci osiguravaju sudsku kontrolu zakonitosti njihovih akata. Pravni poredak daje to pravo svakome, ali nikoga ne sili na to da se istim koristi, nego prepušta njegovoj dispoziciji hoće li se njime koristiti.

Tako je čl. 1. Zakona o parničnom postupku (NN 53/91,91/92,58/93,112/99,88/01,117//03,88 /05,2/07,84/08, 123/08, 57/11,148/11,25/13,89/14-u daljnjem tekstu ZPP) propisano da se tim Zakonom uređuju pravila postupka, na temelju kojih sud raspravlja i odlučuje u sporovima o osnovnim pravima i obvezama čovjeka i građanina, o osobnim i obiteljskim odnosima građana te u radnim, trgovačkim, imovinskim i drugim građanskopravnim sporovima, ako zakonom nije za neke od tih sporova određeno da o njima sud rješava po pravilima kojeg drugog postupka.

$\mathrm{Tu}$ je riječ o sudskim postupcima u pogledu pravnih odnosa u bitnome uređenim normama materijalnog građanskog privatnog prava.Vidi: Gavella, N., o. c., Ibid. i bilješku br. 14.

10 V. više u: Alen Uzelac, „Civilistička i procesualistička redakcija supstancijalnih normi: O neprimjerenoj procesualizaciji nekih materijalnopravnih normi na primjerima ZOO“, Pravni život, Zagreb, vol. 41., br. 3-4/1991., str. 425-451. 
Pri tome građansko materijalno pravo daje procesnom pravu smisao i svrhu postojanja, a procesno pravo sa svoje strane omogućuje materijalnome da se ostvaruje u društvenim odnosima i kada je za to potrebna moć javne vlasti (suda). ${ }^{11}$ Stoga ćemo međusobni odnos materijalnog i procesnog građanskog prava u hrvatskom pravnom sustavu razmotriti sa stajališta uloge građanskog materijalnog prava u postupcima koji se pred sudovima vode u tzv. građanskopravnim stvarima. ${ }^{12}$ Kod toga ćemo razlikovati građanskopravni i sudski spor povodom kojeg se vodi parnični postupak, kojemu naša procesnopravna znanost opravdano pridaje veliku pozornost. ${ }^{13}$ Građanskopravni sporovi koji nastaju među sudionicima radi zaštite njihovih subjektivnih prava prethode obraćanju sudu, a nakon podnošenja tužbe dobivaju značaj sudskog spora, koji će konačno biti riješen pravomoćnom meritornom sudskom odlukom utemeljenoj na relevantnoj materijalnopravnoj i činjeničnoj osnovi.

\section{GRAĐANSKOPRAVNI ${ }^{14}$ I SUDSKI SPOR}

Među sudionicima građanskopravnih odnosa kao specifičnih društvenih odnosa koji su uređeni materijalnopravnim normama građanskog prava ${ }^{15}$ česti su sporovi o međusobnim subjektivnim pravima, kao njihovom licu i dužnostima (obvezama) kao njihovom naličju te o njihovom privatnopravnom statusu. ${ }^{16}$ Sporovi među tim

11 Stoga se doista treba složiti s tvrdnjom prof. Siniše Trive i Mihajla Dike, da bi nesumnjivo građansko procesno pravo izgubilo svoj smisao bez postojanja građanskog prava - jer se zadatak građanskog procesnog prava iscrpljuje u ostvarenju pretpostavaka za zaštitu građanskopravnih ovlaštenja - to ipak građanskom procesnom pravu ne oduzima značaj samostalnog pravnog područja u okviru jedinstvenog pravnog sustava. U mjeri u kojoj je umjesna podjela na javno i privatno građansko pravo, građansko procesno pravo jest specifična grana javnog prava. Za mnoge od njih nema korespondirajućih ustanova na području građanskog prava (npr. za deklaratornu pravnu zaštitu, za pravne lijekove i sl.). Vidi: Triva - Dika, o. c., par. 3/2, str. 12.

12 Vidi više u: Triva - Dika, o. c., par. ag. 3/4, str. 13-18.

13 Tako prof. em. Mihajlo Dika obogaćuje našu pravnu literaturu novim sustavnim djelom o parničnom procesnom pravu u dvanaest svezaka (knjiga) pod zajedničkim nazivom Građansko parnično pravo u izdanju Narodnih novina d.d. Zagreb, od kojih su do sada objavljeni: Stranke, njihovi zastupnici i treći u parničnom postupku (IV. knjiga), Parnične radnje (V. knjiga), Tužba (VI. knjiga), Utvrđivanje činjenica i dokazivanje (VII. knjiga), Sudske odluke i sudska nagodba (IX. knjiga) i Pravni lijekovi (X. knjiga). S nestrpljenjem očekujemo objavu njegovih ostalih svezaka.

14 Građanskopravni spor (građanskopravna stvar) u smislu čl. 1. ZPP-a nije samo onaj spor koji proizlazi iz izričito navedenih odnosa, već je to i svaki drugi spor koji bi se mogao kvalificirati kao građanskopravni spor.

15 Za razumijevanje temeljnih obilježja i načela građanskog prava i njegova položaja u pravnom sustavu potrebno je, pa čak i nužno, najprije sve pravne discipline, odnosno pravna područja, svrstati u dvije skupine ili grane: javno pravo i privatno pravo. Tako u javno pravo pripadaju: ustavno pravo, upravno (materijalno) pravo, kazneno (materijalno) pravo, građansko procesno pravo, kazneno procesno pravo, upravno procesno pravo i međunarodno javno pravo. U privatno pravo pripadaju: obiteljsko pravo, građansko pravo, pomorsko i općeprometno pravo, trgovačko pravo, pravo društva, pravo osiguranja, međunarodno privatno pravo, radno pravo, autorsko pravo i pravo industrijskog vlasništva. Vidi u: Zvonimir Slakoper i Vilim Gorenc, Obvezno pravo (Opći dio), Novi informator, Zagreb, 2009., str. 37-40.

16 Kako se privatnopravni status osoba u njihovim građanskopravnim odnosima sastoji od njihovih subjektivnih prava i obveza, nije ga neophodno posebno spominjati. Nije neophodno ni posebno 
sudionicima ne nastaju uvijek pred sudom, ali mogu dobiti obilježje sudskog spora. To će uslijediti u slučaju kad onaj koji želi da se u pravnom odnosu s drugom osobom ostvari njegovo subjektivno materijalno pravo za koje smatra da mu pripada, a koje mu ova krši, podnese tužbu sudu kojom traži da sud o tom njihovom nastalom sporu donese odluku. Sud će tada provesti parnični postupak ${ }^{17}$ u kojem će sudionici imati ulogu tužitelja i tuženika. ${ }^{18}$ Međutim, njihov građanskopravni spor postoji i nadalje usporedno s parnicom ${ }^{19}$ koju bi sud trebao okončati svojom meritornom odlukom utemeljenom na normama građanskog materijalnog prava. Ova bi se odluka nakon toga trebala odraziti na građanskopravni odnos stranaka. Taj bi odnos nakon odluke suda trebalo uskladiti s onim što je sud odlučio o subjektivnim materijalnim pravima i dužnostima (obvezama) stranaka. Ako do tog dobrovoljnog usklađenja ne dođe, stranke se podvrgavaju autoritetu sudske odluke da se ista realizira preko tijela sudske ili druge javne vlasti u sudskom ovršnom ili kojem drugom nadležnom postupku.

Svaki sudski spor, odnosno parnica, ima svoje procesnopravne i materijalnopravne elemente kojima je krajnji cilj zajednički, a to je ostvarenje onih subjektivnih materijalnih prava i dužnosti (obveza) koje strankama pripadaju na temelju normi materijalnog prava. Procesnopravni element ogleda se u dužnosti suda da postupa prema pravilima građanskog procesnog prava, a materijalnopravni element odražava se u usmjerenosti sudskog postupanja prema donošenju odluke o meritumu spora. Njime će sud odlučiti ima li tužitelj doista ono subjektivno građansko materijalno pravo na kojem se navodno zasniva njegov tužbeni zahtjev, odnosno ima li pravni status koji sebi svojata. Kod toga je potrebno međusobno razlikovati materijalnopravni temelj tužbenog zahtjeva od materijanopravnog temelja sudskog spora koji je tom tužbom pokrenut i presude (odluke) koja će se donijeti o meritumu tog spora. ${ }^{20}$

naglašavati obveze, jer su one u pravnim odnosima naličje subjektivnih prava. Subjektivnom pravu jedne osobe u pravnom odnosu odgovara obveza, odnosno dužnost druge osobe u tom odnosu. Vidi: Gavella, N., o. c., str. 543 i 544, s popratnim bilješkama.

17 Parnični postupak pokreće se na zahtjev stranke koja tvrdi da su njezina subjektivna građanska prava povrijeđena ili ugrožena, pa za njih traži adekvatnu pravnu zaštitu. Parnični postupak provodi se uvijek, ako na temelju izričitog zakonskog propisa nije predviđen neki drugi, npr. izvanparnični ili ovršni postupak.

18 Podnošenjem tužbe uspostavlja se procesnopravni odnos između tužitelja i suda, sadržaj kojega je zahtjev tužitelja da sud donese odluku određenog sadržaja. Nakon što se tužba dostavi tuženiku, i on stupa u procesnopravni odnos sa sudom u kojem on sa svoje strane u pravilu zahtijeva od suda protivnu odluku o tužiteljevom zahtjevu. Ibid i bilj. 21.

19 Parnica je institucija građanskog procesnog prava regulirana ZPP-om; procesno stanje do kojeg dolazi podnošenjem tužbe sudu s ciljem da sud, nakon provođenja određenog postupka, odluči o osnovanosti zahtjeva za pružanjem određene pravne zaštite subjektivnim građanskim pravima za koje se tvrdi da su povrijeđena ili ugrožena.

20 Vidi: Gavella, N., Ibid. Presudom kojom se odlučuje o osnovanosti istaknutog zahtjeva za pružanje pravne zaštite tužbeni zahtjev može biti usvojen ili odbijen u cijelosti ili djelomično. Ako sud ustanovi da nema procesnih pretpostavki za odlučivanje o osnovanosti tužbenog zahtjeva, on neće donijeti meritornu odluku, već će takav zahtjev odbaciti iz procesnih razloga. 


\section{PRAVNA OSNOVA TUŽBENOG ZAHTJEVA}

Svatko ima pravo tražiti da zakonom ustanovljeni neovisni i nepristrani sud pravično i u razumnom roku odluči o njegovim pravima i dužnostima (obvezama), ali to ne znači da ima pravo i na to da sud usvoji bilo kakav njegov tužbeni zahtjev. ${ }^{21}$ Za to je potrebno da je taj zahtjev utemeljen na odgovarajućem tužiteljevom subjektivnom pravu. Je li tako utemeljen ili nije, predmet je sudskog spora. Međutim, predmet sudskog spora redovito se ne svodi samo na to, jer se na protivnoj strani nalazi tuženik koji najčešće ima neke svoje materijalnopravne prigovore na tužbeni zahtjev tužitelja, a ponekad i neke svoje protuzahtjeve. Kada ih ne bi imao, ne bi bilo ni materijalnopravnog elementa spora. Međutim, ti prigovori i protuzahtjevi, kao i sam tužbeni zahtjev tužitelja, u sudskom se sporu u startu zasnivaju tek na navodnoj, više ili manje vjerojatnoj materijalnopravnoj osnovi, koja je izričito navedena ili se pretpostavlja. Materijalnopravna utemeljenost prigovora ili protuzahtjeva, ako ih tužitelj ospori, bit će predmetom sudskog spora kao i sam zahtjev tužitelja.

\subsection{Pretpostavljena pravna osnova}

Svatko može tužbom postaviti svoj tužbeni zahtjev sudu. Da bi sud mogao tom zahtjevu udovoljiti svojom odlukom o meritumu spora, taj bi zahtjev trebao imati odgovarajuću pravnu osnovu, koja se ogleda u subjektivnom materijalnom pravu koje tužitelja ovlašćuje da mu tuženik učini ono što tužitelj zahtijeva, da sud naredi tuženiku. Za mnoge će se tužbene zahtjeve utvrditi da nisu materijalnopravno utemeljeni (osnovani) tj. da tužitelj nema pravo na ono što zahtijeva. Međutim, pravna osnova tužbenog zahtjeva bitna je pretpostavka njegova usvajanja, ali ne i postavljanja. Za očekivati je da će u trenutku podnošenja tužbe pa sve do pravomoćnosti sudske odluke vladati veća ili manja neizvjesnost o tome je li i koliko tužiteljev tužbeni zahtjev doista osnovan.

Tako se podrazumijeva da će kondamnetorna i konstitutivna tužba sadržavati tužiteljevu tvrdnju da mu u odnosu na tuženika pripada subjektivno materijalno pravo na ono što tužbom traži. ${ }^{22}$ Bez obzira na to je li tužitelj u tužbi izričito naveo da mu pripada neko subjektivno pravo prema tuženiku ili se to iz tužbe pretpostavlja, ono je uvijek tek navodna (pretpostavljena), više ili manje vjerojatna materijalnopravna osnova njegova tužbenog zahtjeva. ${ }^{23}$ Sud bi ipak trebao što prije

21 Zahtjev je objektivnim pravom zajamčena mogućnost da se od drugog zahtijeva čin ili propust koji istodobno znači ostvarivanje subjektivnog prava. Vidi u: Klarić, Petar i Vedriš, Martin, Građansko pravo, Narodne novine, Zagreb, 2009., str. 67 (u daljnjem tekstu: Klarić - Vedriš, o. c.). Ovi autori smatraju da zahtjev ne izvire iz subjektivnog prava nego iz norme objektivnog prava, te da je zahtjev samo u pravilu redoviti pratitelj subjektivnog građanskog prava.

22 Kao pravna osnova kondamnetornih i konstitutivnih zahtjeva uvijek će biti neko tužiteljevo subjektivno materijalno pravo. Kod dekaratornih tužbenih zahtjeva je drukčije, jer je njihova neposredna svrha procesnopravne naravi.

23 Prema našem građanskom parničnom procesnom pravu tužba ne mora, premda može, sadržavati navod o građanskopravnoj osnovi tužbenog zahtjeva. Vidi: Triva - Dika, o. c., str. 413-416. te odredbu čl. 186. st. 3. ZPP-a. Ovu postupkovnu odredbu treba razumjeti u smislu da sud nije vezan 
sagledati na kojem to navodnom subjektivnom materijalnom pravu tužitelj zasniva svoj tužbeni zahtjev. Ako ga tužitelj nije izričito istakao u tužbi, sud će svrhovito postupiti kada već u stadiju pripremanja glavne rasprave ukloni moguće nedoumice o tome na čemu to tužitelj temelji svoj tužbeni zahtjev.

Podnošenje tužbe, kao i poduzimanje daljnjih procesnih radnji, u biti se odnosi na ostvarivanje ili zaštitu subjektivnog prava za koje tužitelj smatra ili tvrdi da je njegovo ili se pak odnosi na neku njegovu specifičnu uporabu. Sud ne smije tražiti neku drugu materijalnopravnu osnovu tužbenog zahtjeva prije pravomoćnosti presude. Nitko, pa ni sam sud, ne može pouzdano znati je li postavljanje tužbenog zahtjeva bila dopuštena tužiteljeva dispozicija predviđena subjektivnim pravom koje je ga na to ovlašćuje. Ako takva osnova i postoji kao neko drugo tužiteljevo subjektivno pravo različito od onoga na kojemu temelji svoj tužbeni zahtjev, na tužitelju je, a ne na sudu, da se tim pravom koristi ili ne koristi, prema svojoj volji. Stoga prof. Gavella opravdano upozorava da je potreban veliki oprez pri primjeni pravila iz odredbe čl. 368. st. 2. ZPP-a, prema kojoj će drugostupanjski sud presudom odbiti žalbu kao neosnovanu i potvrditi prvostupanjsku presudu, ako utvrdi da je prvostupanjski sud pogrešno primijenio materijalno pravo, ali da je pravilnom primjenom materijalnog prava trebalo jednako odučiti o tužbenom zahtjevu.

\subsection{Pravna osnova kondamnetornog tužbenog zahtjeva}

Kako bi sud mogao usvojiti kondamnetorni tužbeni zahtjev tužitelja, on bi se trebao temeljiti na utuživom materijalnom subjektivnom pravu koje svojeg nositelja ovlašćuje tražiti od tuženika onu činidbu (pozitivnu ili negativnu) čije ispunjenje tužitelj traži da sud naloži tuženiku. To znači da se taj tužbeni zahtjev treba temeljiti na takvom subjektivnom pravu koje je utuživo, ${ }^{24}$ a to nikako nisu sva subjektivna građanska prava. Tako apsolutna subjektivna prava ${ }^{25}$ kao što su pravo vlasništva i

tužiteljevim shvaćanjem, odnosno tumačenjem normi materijalnog prava (građanskog, odnosno nekog drugog privatnog prava u objektivnom smislu), ni kada ga je tužitelj izričito naveo u svojoj tužbi. Tu se odredbu ne bi smjelo shvatiti u smislu da sud nije vezan tužiteljevim navodom o tome koje to subjektivno pravo želi ostvariti ili zaštititi u parnici koju je pokrenuo svojom tužbom, jer ukoliko bi se tako shvatilo, povrijedilo bi se slobodu pojedinca da se prema svojem nahođenju služi ili ne služi svojim subjektivnim pravima. Zato je za prihvatiti Dikinu tvrdnju da sud jedino nije vezan tužiteljevom pravnom kvalifikacijom spora, ali je vezan tužiteljevom dispozicijom i onim subjektivnim pravom koje je prema tužiteljevoj tvrdnji materijalnopravni temelj njegova tužbenog zahtjeva. Vidi: Gavella, N., o. c., str. 545-546 i bilješku 25.

24 Tužbe zbog smetanja posjeda također su kondamnetorne tužbe. I one moraju imati svoju materijalnopravnu osnovu u odgovarajućem utuživom pravu-zahtjevu usmjerenu na osobu koja je protupravno smetala (oduzela u užem smislu) posjed. Za onoga kojemu je posjed oduzet ili smetan, ne proizlaze prava-zahtjevi iz nekog njegova subjektivnog prava (jer posjed nije subjektivno pravo) koje bi trebalo ostvariti ili zaštititi, nego iz materijalnopravnih normi koje pod zakonom određenim pretpostavkama daju posjedniku pravo na zaštitu (čl. 21.-27. ZoV-a). Te zakonske norme određuju i neke posebnosti u pogledu prava-zahtjeva za zaštitu posjeda i njezinog ostvarivanja, ali one ne odudaraju od ostalih prava-zahtjeva na kojima se trebaju temeljiti kondamnetorne tužbe. V. više: Gavella, N., o. c., str. 547-550.

25 To su ona subjektivna građanska prava koja djeluju prema svakome (erga omnes), kao npr. pravo vlasništva, prava osobnosti i dr. Njih može svatko povrijediti, ali nositelj apsolutnog prava može svoje pravo i ostvarivati protiv svakoga. 
druga stvarna prava, prava osobnosti, nasljedno pravo, autorsko pravo, nisu sama po sebi utuživa jer su usmjerena prema svima, a ne samo prema određenoj osobi. Tek povredom takvog apsolutnog prava, kada određena osoba ne udovoljava svačijoj dužnosti (obvezi) poštovanja tog prava, nastaje situacija u kojoj treba u odnosu s tom osobom ostvariti zaštitu tog povrijeđenog subjektivnog prava. U takvom slučaju će iz povrijeđenog apsolutnog prava za njegova nositelja nastati novo subjektivno građansko pravo koje ga ovlašćuje od povreditelja zahtijevati onakvo činjenje kojim bi se realiziralo, odnosno zaštitilo apsolutno pravo koje je u odnosu s tom osobom povrijeđeno ili neostvareno. Ta nova subjektivna građanska prava ovdje se nazivaju pravima-zahtjevima ${ }^{26}$ za razliku od onih subjektivnih prava iz kojih su ta prava povredom proizišla.

Prava-zahtjevi uvijek su usmjereni prema nekoj određenoj osobi te ovlašćuju svojeg nositelja da od te osobe zahtijeva određeno činjenje koje je ona dužna ispuniti. Kada ta njezina dužnost (obveza) dospije na izvršenje, jer nije ispunjena dobrovoljno, pravo-zahtjev je moguće utužiti ${ }^{27}$ sve dok ne nastupi njegova zastara. ${ }^{28}$ Prava-zahtjevi su prikladni biti neposredni materijalnopravni temelj kondamnetornih tužbenih zahtjeva. ${ }^{29}$ Kada tužitelj postavi kondamnetorni zahtjev, tada je njegova utemeljenost na pravu-zahtjevu samo navodna. Ona je tada više ili manje vjerojatna, a je li takav zahtjev materijalnopravno utemeljen, utvrdit će sud u parničnom postupku.

26 Često se o pravima koja se nazivaju prava-zahtjevi govori kao o materijalnopravnim zahtjevima. $\mathrm{Na}$ taj način ih se razlikuje od procesnopravnih zahtjeva, što je dobro, jer su materijalnopravne naravi. Pri tome prijeti opasnost da se izgubi iz vida kako su to potpuna, posebna subjektivna prava koja se nazivaju pravima-zahtjevima koji imaju materijalnopravnu, a ne procesnopravnu egzistenciju, pa ih se $\mathrm{i}$ bez sudjelovanja suda može postavljati i ostvarivati.

27 Pravo-zahtjev može se utužiti, ali ne mora. Hoće li se nositelj poslužiti ovim svojim subjektivnim pravom i kako, ovisi o njegovoj prosudbi i dispoziciji. Prof. Gavella smatra da su na opasnom putu oni koji predlažu obvezatno sudjelovanje u izvansudskom postupku mirenja ili bilo kojem drugom građanskopravnom postupku pred sudom, jer se time bez dovoljno razloga odstupa od načela dispozitivnosti na kojem je izgrađeno građansko pravo. Onaj koji bi se ustručavao ostvarivati i štititi svoje subjektivno građansko pravo pred sudom, trpjet će zbog toga nepovoljne posljedice. Vidi: Gavella, N., o. c., Ibid i bilješke br. 29 i 30 .

28 Utuživost subjektivnih prava njihovo je građanskopravno svojstvo koje pravo-zahtjev gubi, ako i kada nastupi zastara. Time ne prestaje ono subjektivno pravo iz kojeg pravo-zahtjev proistječe, ni samo to pravo, nego samo prestaje njegova utuživost. Dakle, pravo-zahtjev više se ne može ostvariti putem suda, ali se i nadalje može valjano ostvariti dobrovoljno i izvansudski. Kada iz subjektivnog prava proiziđe za njegova nositelja pravo-zahtjev prema određenoj osobi, pravo-zahtjev je njegovo novo subjektivno građansko privatno pravo pored onoga iz kojeg je pravo-zahtjev proizišao (time što iz nekog prava proiziđe pravo-zahtjev, to pravo ne prestaje). Pravo-zahtjev je potpuno pravo, premda u svezi s onim pravom iz kojega je proizišao. Među njima postoji sveza, subjektivno pravo iz kojeg je pravo-zahtjev proizašao daje zahtjevu pravni temelj njegova postojanja, a on sa svoje strane služi ostvarivanju i zaštiti tog prava. Međutim, pravo-zahtjev ne mora trajati za čitava trajanja prava iz kojeg proizlazi, jer može samostalno prestati i ranije, kao npr. ispunjenjem, zastarom ili odreknućem. V. Gavella, N., Ibid., bilj. 31 i 32 .

29 Posredni materijalnopravni temelj kondamnetornih zahtjeva je apsolutno subjektivno građansko privatno pravo iz kojega proizlazi pravo-zahtjev. Posredstvom tog apsolutnog prava kao svog neposrednog temelja, kondamnetorni tužbeni zahtjev može imati i daljnje posredne materijalnopravne temelje (prava iz kojih je to apsolutno pravo izvedeno, još dalje ona prava iz kojih su ta prava izvedena itd.). Na kraju tog niza svakako će biti neke norme materijalnog prava kao krajnji pravni temelj tužbenog zahtjeva. Gavella, N., Ibid. 
Nisu samo apsolutna subjektivna građanska prava sama po sebi neutuživa, nego su to i relativna subjektiva građanska prava, ${ }^{30}$ premda svoje nositelje ovlašćuju na činidbu. Tako se tek mogu utužiti prava-zahtjevi koji proiziđu iz povrijeđenog relativnog prava, a proizići će, ako osoba koja nositelju relativnog prava duguje činidbu, tu činidbu nije ispunila ni nakon dospjelosti. Iz relativnog subjektivnog prava (npr. iz vjerovnikove tražbine prema dužniku) također će, ako i kada nastane potreba da se takvo pravo ostvari ili zaštiti u odnosu s tom osobom, kao dužnikom za nositelja takvog prava, kao vjerovnika proizlaziti novi utuživi subjektivni zahtjev, ${ }^{31}$ koji će ga ovlašćivati dok ne zastari da od onog tko je njegovo pravo povrijedio zahtijeva činjenje kojim će se ono ostvariti. ${ }^{32}$

Kada dužnik vjerovniku ne ispuni dužnu činidbu, premda je njegova obveza dospjela na ispunjenje, povrijedio je vjerovnikovo relativno pravo (vjerovnikovu tražbinu, potraživanje), pa je time za vjerovnika nastao pravo-zahtjev koji ga ovlašćuje od dužnika zahtijevati dužnu činidbu i sudskim putem. Pravo-zahtjev može se utužiti, pa je prikladan biti neposredna materijalnopravna osnova kondamnetornog tužbenog zahtjeva. ${ }^{33}$ Dok dužnikova obveza nije dospjela za ispunjenje, dužnik još nije povrijedio vjerovnikovo pravo na tu njegovu činidbu, a možda ga neće ni povrijediti, pa vjerovnik još nema pravo zahtijevati ispunjenje te činidbe od dužnika. On, dakle, ima pravo na činidbu, ali još nema utuživ pravozahtjev na njezino ispunjenje. Uz ova materijalnopravna pravila, u našem pravnom sustavu već je dulje vrijeme na snazi i posebna procesnopravna odredba kojom se unaprijed uzima nastanak prava-zahtjeva iz relativnih prava. ${ }^{34}$ Tako čl. $186 \mathrm{c}$. ZPP-a

30 Relativna su subjektivna građanska prava ona koja djeluju samo između točno određenih subjekata - inter partes. Tu je unaprijed poznato koja strana može povrijediti takvo pravo. Relativna prava su npr. obvezna prava.

31 Vidi: Pavlović, Mladen, Zahtjev u građanskom i procesnom pravnom smislu, PuG, Zagreb, br. $1 / 2007$.

32 Ista je situacija i s ostalim pravima koja svojim nositeljima daju ovlasti zahtijevati neku činidbu od određene osobe (npr. s pravom vlasnika povlaštene nekretnine koji ima služnost kolnika na poslužnoj nekretnini, pa ga ta ovlašćuje da od vlasnika poslužne nekretnine zahtijeva trpljenje radnji kojima se ostvaruje to pravo služnosti). Tek ako i kada osoba koja je dužna nositelju prava izvršiti neku činidbu (pozitivnu ili negativnu) to ne učini, za njega nastaje pravo-zahtjev da mu izvrši tu činidbu (npr. da plati neki obrok stvarnog tereta, propusti prijevoz preko nekretnine i sl).

Pravo-zahtjevi koji nastaju povredom relativnih prava nesamostalna su prava, jer ovise o onom relativnom pravu (tražbini) iz koje su proistekli, s njima su u odnosu sporednih (akcesornih) prava prema glavnom pravu. Ti su zahtjevi još nesamostalniji od onih koji proizlaze iz apsolutnih prava gospodariti objektom. Naime, s prestankom relativnog prava iz kojeg proizlazi pravo-zahtjev ujedno prestaje i pravozahtjev (ne postoji i obrnuti slučaj da prestankom prava-zahtjeva, npr. zastarom, ne prestaje relativno subjektivno građansko pravo iz kojeg je proizašao pravo-zahtjev koji je zastario). Vidi: Gavella, N., o. c., str. 348. i bilješke br. 34. i 35 .

33 Prof. Gavella smatra da to nije jasno vidljivo u onim obveznim odnosima u kojima dužnikova obveza dospijeva odmah. U njima, ako dužnik ne ispuni dužnu činidbu odmah, on vrijeđa vjerovnikovo pravo na činidbu odmah nakon što je ono nastalo, pa vjerovnik nema utuživ pravo-zahtjev prema tuženiku. Ta dva prava koincidiraju, pa ih nije lako razlikovati. Izgleda kao da je vjerovnikovo pravo na činidbu utuživo premda je zapravo utuživ samo zahtjev koji je iz toga prava proizašao njegovom povredom. V. Gavella, N. o. c., str. 549 i bilješku 36.

$34 \quad$ Vidi odredbe čl. 186.c st. 1. i 3. ZPP-a, prema kojima tužitelj koji učini vjerojatnim da dužnik ozbiljno dovodi u pitanje postojanje njegove još uvijek nedospjele tražbine ili da će morati sudskim putem ostvarivati svoju tražbinu nakon što ona dospije ili da iz drugih razloga ima za to pravni interes, može i 
zakonodavac je smiono zahvatio u uvijek osjetljiv međusobni odnos materijalnog $\mathrm{i}$ procesnoga prava. Time je nositelj relativnog prava stekao mogućnost podnošenja tužbe na temelju samo tog svojeg još nepovrijeđenog prava. Vjerovnik ne mora čekati da dužnik povrijedi njegovo relativno pravo, pa da tek tada protiv njega nastane pravo-zahtjev, nego se uzima kao da je taj zahtjev za njega nastao, premda je očigledno da još nije, a možda čak neće ni nastati. Paradoksalno je da nositelj relativnog materijalnog prava može na temelju takvog svojeg ovlaštenja ishoditi i pravomoćnu presudu kojom će sud naložiti dužniku da ispuni vjerovniku dužnu činidbu, iako vjerovnika kao tužitelja to njegovo subjektivno pravo ne ovlašćuje od dužnika zahtijevati ispunjenje prije nego što ta dužnikova obveza dospije. Ali, na temelju presude donesene bez posebne materijalnopravne osnove, ovrha se može tražiti tek nakon dospjelosti tražbine. Očito je da su zakonodavca neke posebne okolnosti navele da otvori ovakvu procesnopravnu mogućnost za podnošenje i usvajanje zahtjeva i prije nego što je nastao zahtjev-pravo koji bi tome trebala biti materijalnopravna osnova. ${ }^{35}$

Takvo procesnopravno uređenje proturječi građanskopravnom uređenju, narušavajući međusobni odnos normi materijalnog i procesnog građanskog prava u parnicama i njihovu suradnju u rješavanju sudskih sporova. Međutim, ta suradnja i dalje postoji, jer sud može kondamnetorni zahtjev usvojiti i ranije, ali to će biti jalov posao dokle god ono što tužitelj zahtijeva ne dospije za ispunjenje te nastane pravozahtjev, jer do tada neće moći tražiti ovrhu. Tek ako naknadnim dospijećem nastane pravo-zahtjev kao pravna osnova onoga što je tužitelj zahtijevao, presuda koju je sud o tome donio moći će kao plod suradnje materijalnog i procesnog građanskog prava postati i ovršnom, pa na taj način ispuniti svrhu zbog koje je tužitelj zatražio od suda odluku po čl. 186.c ZPP-a.

\subsection{Pravna osnova konstitutivnog tužbenog zahtjeva}

Da bi se mogao usvojiti neki konstitutivni tužbeni zahtjev, u pravilu bi isti trebao imati materijalnopravnu osnovu u odgovarajućem subjektivnom građanskom pravu. Kao neposredna osnova takvih zahtjeva dolaze u obzir, baš kao i kod onih kondamnetornih, utuživi prava-zahtjevi kakvi nastaju iz subjektivnih građanskih privatnih prava kada ih treba sudskim putem ostvariti ili zaštititi u odnosu $\mathrm{s}$ određenom osobom. Međutim, ipak se razlikuju od kondamnetornih zahtjeva po tome što nastaju iz one vrste subjektivnih prava koja se nazivaju potestativnim ili preobražajnim pravima. To su prava kojima se odobrava ili utječe na pravni odnos,

prije dospjelosti tražbine zatražiti od suda tuženiku naložiti da mu ispuni dužnu činidbu u vrijeme njezine dospjelosti. Vrijeme dospjelosti tražbine treba biti određeno naznačeno u tužbenom zahtjevu. Ovrha na temelju presude kojom je prihvaćen zahtjev iz st. 1. ovog članka može se tražiti tek nakon dospjelosti tražbine. Uz pravni interes za njihovu primjenu imamo niz mogućnosti (op. aut).

35 Unošenje odredbi čl. 186.c ZPP-a u naš pravni sustav bilo je motivirano time što je u poslovanju mnogih pravnih subjekata uzela maha praksa da kao dužnici ne udovoljavaju svojim obvezama dokle god na to ne budu prisiljeni. 
a katkada i na pravnu moć. ${ }^{36}$ Prava te vrste ovlašćuju svoje nositelje na to da svojim jednostranim voljnim aktima, ali često i posredstvom odluke suda koju nositelj prava tek treba ishoditi, utječu na neki pravni odnos s određenom osobom. ${ }^{37}$ Budući da iz njih proizlaze prava-zahtjevi, potestativna su prava posredne pravne osnove konstitutivnih tužbi. Daljnja posredna pravna osnova bit će im i materijalnopravne norme iz kojih ta prava proizlaze.

Redovno takva prava nisu utuživa, nego tek ako i kada nastane situacija u kojoj to pravo, pošto je dospjelo, treba i ostvariti u odnosu s određenom osobom. Iz potestativnog prava će za njegova nositelja proisteći pravo-zahtjev prema toj osobi. ${ }^{38}$ Materijalopravni temelj konstitutivnih tužbi, kao i kod kondamnetornih, treba biti tužiteljev navodni pravo-zahtjev odgovarajućeg sadržaja usmjeren prema tuženiku. Razlika od prava zahtjeva koji su pravnom osnovom kondamnetornih tužbi jest $u$ porijeklu prava-zahtjeva. ${ }^{39}$ Da bi sud mogao udovoljiti zahtjevu koji je postavljen konstitutivnom tužbom, mora biti utemeljen na pravu-zahtjevu koji je proizišao iz potestativnog prava, a ono možda na nekom drugom subjektivnom pravu, ovo na nekom daljnjem itd., sve do utemeljenja na odgovarajućim materijalnopravnim normama. ${ }^{40}$

$36 \quad$ Katkada se za tu vrstu prava rabi naziv pravna moć, premda je pojam pravne moći širi od pojma preobražajnog prava. U širem smislu riječi, pravna je moć svaka privatna pravna vlast koja nositelju subjektivnog prava pripada $\mathrm{u}$ određenom građanskopravnom (privatnopravnom) odnosu na temelju normi objektivnog prava, makar ona i ne proizlazi iz nekog subjektivnog prava (npr. moć prihvaćanja ponude ugovora, čime će tek nastati pravo iz ugovora). Zbog te višeznačnosti, bolje je izbjegavati suviše širok naziv pravna moć. V. Gavella, N., o. c., str. 551 i bilješke.

37 Npr. nekom sudioniku ugovornog odnosa pripada potestativno pravo otkaza, raskida ili odustanka od njega (čime će uzrokovati prestanak tog odnosa) ili dužniku alternativne obveze pripada potestativno pravo odlučivanja koju će činidbu ispuniti da bi se oslobodio obveze kao i glede ostalih ili nositelju prava prvokupa pripada potestativno pravo kupnje stvari pod jednakim uvjetima pod kojima je stvar prodavatelj ponudio na prodaju nekom drugom.

38 Npr. ispunjenjem naplatnog ugovora nastaje ispuniteljeva obveza da odgovara za nedostatke ispunjenja, a ujedno kao njezin dodatak za osobu koja je primila ispunjenje odgovarajuće subjektivno potestativno pravo zahtjeva otklanjanja nedostatka. Pošto obveza, odgovornosti za nedostatke ispunjenja dospije, iz potestativnog prava nastaje za njegova nositelja utuživ pravo-zahtjev prema osobi koja je obvezna odgovarati za nedostatke tog neispunjenja.

39 Tako prof. Gavella ističe da u pojedinostima postoje brojne razlike među određenim podvrstama potestativnih prava što se odražava na pravima-zahtjevima koji nastaju iz tih i takvih prava. U bitnome je, ako zanemarimo pojedinosti situacija poput one kod kondamnetornih tužbi. Gavella, N., o.c., str. 552. i bilj. 44.

40 Kao što je već navedeno, u svezi s kondamnetornim tužbenim zahtjevima na snazi je i posebna procesnopravna odredba čl. 186.c ZPP-a prema kojoj je nositelj potestativnog prava ovlašten na temelju samog tog prava utužiti pa i ishoditi pravomoćnu presudu prije nego što dospije za ispunjenje ono što zahtijeva. Procesnopravna situacija je u pogledu materijalnopravne osnovanosti konstitutivnih tužbenih zahtjeva jednaka kao i u pogledu kondamnetornih s jednakim pravnim posljedicama. Međutim, i tada će za to da bi se postigla bitna svrha podnošenja tužbe i vođenja parničnog postupka biti potrebna suradnja meterijalnog i procesnog građanskog prava, jer tako donesena presuda neće biti ovršna dok dospjećem potestativnog prava naknadno ne nastane pravo-zahtjev koji je materijalnopravna osnova umnaprijed usvojenog konstitutivnog zahtjeva. 


\subsection{Pravna osnova deklaratornog tužbenog zahtjeva}

Deklaratorni tužbeni zahtjev postavljen tužbom na utvrđenje ili prejudicijelnim zahtjevom za utvrđenje po mnogo čemu se razlikuju od kondamnetornog i konstitutivnog zahtjeva. Za razliku od njih, deklaratorni zahtjev nije neposredno usmjeren na ostvarenje bilo kojih subjektivnih materijalnih prava tužitelja u njegovu pravnom odnosu s tuženikom. Deklaratornim zahtjevom tužitelj ne zahtijeva od suda da tuženiku naloži kakvo činjenje ili nečinjenje, ni na zahtjevu da svojom odlukom utječe na neki pravni odnos tužitelja i tuženika. Tužitelj samo zahtijeva da sud svojom presudom utvrdi postojanje ili nepostojanje nekog spornog subjektivnog građanskog privatnog prava ili pravnog odnosa ${ }^{41}$ odnosno istinitost ili neistinitost neke isprave ${ }^{42}$ kako bi to utvrđenje, nakon što postane pravomoćno, za tuženika bilo mjerodavno (presuđena stvar). Takvo utvrđenje trebalo bi omogućiti ili olakšati uspjeh u nekom drugom postupku pred sudom ili kojim drugim tijelom javne vlasti. Neposredna funkcija tužbe na utvrđenje zapravo je procesnopravne, a ne materijalnopravne prirode. Nakon što sud usvoji svojom odlukom tužiteljev deklaratorni tužbeni zahtjev i kada ta odluka postane pravomoćna, materijalnopravni odnos stranaka ostaje onakav kakav je bio do tada barem prividno. ${ }^{43}$ Takva je situacija i s prejudicijelnim zahtjevom na utvrđenje. ${ }^{44}$ Zbog takve njihove funkcije, neposredna pravna osnova deklaratornog zahtjeva za sud nije materijalnopravne naravi. Stoga ni posredna pravna osnova deklaratornog zahtjeva nije materijalnopravne, nego procesnopravne prirode - tužiteljev pravni interes za utvrđenje koje traži prema odredbi čl. 187. st. 2. ZPP-a. Međutim, iza toga se krije materijalnoprani element spora stranaka.

41 Vidi: čl. 187. st. 1. ZPP-a. Deklaratornom tužbom ne može se zahtijevati utvrđenje činjenica, osim činjenice postojanja ili nepostojanja neke isprave i kada posebni propisi predviđaju takvu mogućnost (npr. utvrđivanja činjenice očinstva).

42 Riječ je o subjektivnim pravima ili pravnim odnosima koji postoje ili su postojali, ali ne $i$ takvima koji će tek možda u budućnosti nastati. Vidi: Grbin, Ivo, „Glavne značajke tužbe na utvrđenje“, Liber amicorum in honorem Jadranko Crnić, Zagreb, 2009., str. 968. (u daljnjem tekstu: Grbin, I., o. c.).

43 To je u pravilu. Iznimno od toga, podnošenje ili nepodonošenje nekih vrsta deklaratornih tužbi ipak može utjecati na subjektivna prava stranaka. Naime, podnošenje nekih posebnih vrsta deklaratornih tužbi dopušteno je jedino unutar nekih rokova s prekluzivnim djelovanjem (npr. tužba za utvrđenje očinstva, opozicijskih i opugnacijskih tužbi), pa ukoliko tužba ne bude podnesena unutar roka, tužitelju će prestati ona subjektivna prava za koja je propustio tražiti da ih sud utvrdi. I obratno, pravodobnim podnošenjem takve tužbe na utvrđenje, održat će se egzistencija tih prava.

44 Dika, Mihajlo, „Prejudicijelni zahtjev za utvrđenje“, Liber amicorum in honorem Jadranko Crnić, Zagreb, 2009., str. 985-1000. 


\section{MATERIJALNOPRAVNA I ČINJENIČNA OSNOVA SPORA}

\subsection{Materijalnopravna osnova spora}

Predmet sudskog spora jest materijalnopravna osnovanost kondamnetornog ili konstitutivnog tužbenog zahtjeva te tuženikovih prigovora i protuzahtjeva tuženika. Odluka o meritumu takvog spora ovisi o ocjeni materijalnoprave osnovanosti tužbenog zahtjeva, odnosno o tome je li takav zahtjev i u kojoj mjeri zasnovan na odgovarajućem subjektivnom pravu. Odgovor na to sud će naći u provovedenom parničnom postupku koji se vodi prema pavilima procesnog prava, uvažavajući pri tom ustavno pravo obiju stranaka ne pravično suđenje. ${ }^{45}$ To će predstavljati traženje odgovora na materijalnopravno pitanje kakva treba biti sudska odluka o meritumu spora, a kriterij za ocjenu kakav treba biti daju norme materijalnog građanskog privatnog prava. ${ }^{46}$

Primjenjujući ih s obzirom na ono što je o odlučnim činjenicama spoznao tijekom postupka, sud će zaključiti treba li svojom odlukom usvojiti ili odbiti tužbeni zahtjev u cijelosti ili djelomično. ${ }^{47}$ Kada je spor o deklaratornom tužbenom zahtjevu, odnosno kada sud treba odlučiti o prejudicijelnom deklaratornom zahtjevu predmet spora je u krajnjoj liniji materijalnopravne prirode.

Sudskisporoviodeklaratornimtužbenimzahtjevimanikakonisumaterijalnopravno neutralni, jer tužitelj takav zahtjev postavlja da bi ishodio pravomoćnu odluku o meritumu, kojom će dobiti sredstvo s kojim će u daljnjem postupku pred sudom ili upravnim tijelom javne vlasti utjecati na svoje materijalnopravne odnose s tuženikom ili trećim osobama. ${ }^{48} \mathrm{Kada}$ se i postavi pitanje tužiteljevog pravnog

45 Pravo na pravično (pošteno) suđenje jest najvažnije procesno ljudsko pravo. Ono je u hrvatskom pravnom sustavu uvedeno Ustavom RH (čl. 29. st. 1. Ustava) i temelji se na više ratificiranih međunarodnih konvencija od kojih je najvažnija Europska konvencija za zaštitu ljudskih prava i temeljnih sloboda (čl. 6. st. 1. Konvencije objavljene u NN Međunarodni ugovori 18/97 te prečišćeni tekst 6/99 s ispravkom u br. 8/99). U parničnom postupku stranke će poduzimati procesne radnje kako bi ishodile mjerodavnu sudsku odluku o tome kakva subjektivna prava, odnosno koja i kakva privatna pravna vlast pripada pojedinoj stranci, da bi nakon toga tu vlast i ostvarile sudskim putem.

46 Bitno obilježje svih građanskih prava jest u tome da ona neposredno ili posredno proizlaze iz normi građanskog materijalnog prava u objektivnom smislu, koja su im nepostredni li posredni pravni temelj. Stoga će privatna pravna vlast nositelja subjektivnog građanskog prava kada je on ostvari $\mathrm{u}$ društvenim odnosima biti posredstvom tog njegova subjektivnog prava utemeljena na građanskom pravu u objektivnom smislu. Tako je to u suvremenim pravnim porecima kontinentalne Europe, iako nije uvijek i svugdje tako bilo, niti je to i danas. Gavella, N., o. c., str. 554. i bilj. 54.

$47 \quad$ Ukoliko, prema kriteriju koji mu daju materijalnopravne norme, sud zaključi da tužbeni zahtjev nema svoju pravnu osnovu u subjektivnom materijalnom (građanskom ili nekom drugom privatnom) pravu koje tužitelja ovlašćuje na ono tuženikovo činjenje ili nečinjenje za koje je tužitelj zatražio da ga sud naloži tuženiku, zaključit će dalje da taj zahtjev nije materijalnopravno osnovan, pa će ga svojom odlukom odbiti. Tek ako i ukoliko dođe do zaključka da tužitelj u svojem materijalnopravnom odnosu s tuženikom ima ono subjektivno materijalno (građansko ili koje drugo privatno) pravo koje je pravna osnova njegova tužbenog zahtjeva, sud će morati (u granicama procesnopravnih mogućnosti) usvojiti tužbeni zahtjev u cijelosti ili djelomično. Vidi čl. 338. st. 3. u svezi s čl. 333. st. 3. ZPP-a.

$48 \quad$ Kada tužitelj od suda traži utvrđenje da je njegov ugovor s tuženikom ex lege ništetan, jer su npr. fiktivan predmet njihova spora subjektivna materijalna prava koja bi na temelju tog ugovora postojala 
ineresa iz čl. 187. st. 2. u svezi sa st. 1. ZPP-a, redovito je to pitanje o spornom materijalnopravnom odnosu stranaka i mogućem učinku zatraženog pravomoćnog utvrđenja za taj njihov odnos. Naime, pravni interes postoji kada nekom pravu tužitelja prijeti aktualna opasnost, time što tuženik ozbiljno ugrožava neko tužiteljevo pravo ili sebi svojata neko pravo prema tužitelju i kada je pravomoćna deklaratorna presuda koju tužitelj nastoji ishoditi prikladna za otklanjanje te opasnosti. ${ }^{49}$ Bilo da je deklaratorni zahtjev postavljen tužbom za utvrđenje, bilo da je postavljen kao prejudicijelni deklaratorni zahtjev, predmet spora među strankama je u krajnjoj liniji postojanje nekog navodnog tužbiteljeva subjektivnog materijalnog prava u odnosu prema tuženiku ili postojanje nekog tužiteljeva pravnog statusa od utjecaja na materijalnopravni odnos ili odnose tužitelja s tuženikom. Ovim se sporom teži rješavanju spornog materijalnopravnog odnosa stranaka.

\section{2. Činjenična osnova spora}

Svaki spor ima i svoju činjeničnu osnovu, odnosno zbir činjenica koje su pravno relevantne za prosudbu materijalnopravnog odnosa stranaka, a time i za ocjenu osnovanosti tužbenog zahtjeva. Iako se ponekad govori o pravnonormativnim činjenicama ili o pravnoproizvodnoj činjeničnoj osnovi, to se, prema prof. Gavelli, ne bi smjelo doslovno shvatiti. Činjenice same po sebi nisu, niti mogu biti pravnoproizvodne. Postojanje nekih činjenica može biti tek pretpostavka koja će se trebati ispuniti u stvarnosti, da bi iz pravnih normi za neku osobu proizišlo neko subjektivno pravo, odnosno da bi se postojeće pravo promijenilo ili prestalo. Ako u nekom slučaju činjenice budu onakve kakve pravna norma za to predviđa, nastat će, izmijenit će se ili će prestati neko subjektivno pravo. Međutim, to se neće dogoditi kao proizvod tih činjenica, nego kao posljedica djelovanja onih materijalnopravnih normi koje su odredile da će posljedica postojanja te vrste činjenica biti nastanak, promjena ili prestanak tog subjektivnog prava.$^{50}$ Upravo zbog te uloge koju činjenice imaju u nastanku, promjeni ili prestanku subjektivnih materijalnih prava, postoji sveza između materijalnopravnog elementa sudskog spora i njegova činjeničnog stanja. Spoznaja činjeničnog stanja u spornom pravnom odnosu omogućuje zaključak o materijalnopravnoj osnovi sudskog spora. Međutim,

da ugovor nije ništetan (odnosno obveze kao naličje tih prava u pravnom odnosu). Kada se traži utvrđenje očinstva, predmet spora je tužiteljev pravni status tuženikova djeteta, a i sva međusobna subjektivna materijalna prava i obveze koje čine pravni odnos djeteta i roditelja. Kada tužitelj traži uvrđenje da je tuženikova odluka o otkazu ugovora o radu ništetna, predmet spora je tužiteljev pravni satus u radnom odnosu, a i sporna subjektivna materijalna prava i obveze koji u tom odnosu pripadaju tužitelju. Kada tužitelj traži utvrđenje da je ostaviteljeva oporuka ništetna, predmet njihova spora je pravni status ostaviteljeva nasljednika, nasljedno pravo i sve ono od čega se sastoji položaj nasljednika ili pak drugo pravo nasljednopravne prirode (npr. pravo na legat) koje bi mu na temelju te oporuke pripadalo, da ona nije ništetna itd. Vidi: Gavella, N., o. c., str. 555. i bilješku 56.

49 Vidi: Grbin, I., o. c., str. 972-973.

50 Pravnoproizvodne su samo materijalnopravne norme, a ne činjenice (iz odgovarjućih pravnih izvora: Ustava, zakona, podzakonskih i drugih akata) koje određuju da će subjektivna prava nastati, promijeniti se ili prestati pod pretpostavkom da činjenice budu onakve kakve te pravne norme za to predviđaju. V. Gavella, N., o. c., str. 556 i bilj. 58. 
istinita spoznaja činjenica jednako je teška koliko je i važna. ${ }^{51}$ Ukoliko se u sudskom sporu ne utvrdi relevantno istinito činjenično stanje, to za sobom povlači pogrešnu ocjenu materijalnopravnih, a ponekad i procesnopravnih elemenata spora. ${ }^{52}$

\section{ULOGA MATERIJALNOG PRAVA U SUDSKOM POSTUPKU I ODLUČIVANJU}

\subsection{Uloga materijalnog prava u utvrđivanju činjenica}

Sud koji vodi parnicu upravlja postupkom prema procesnim pravilima, ali nikako neovisno o pravilima materijalnog prava. Prema odgovarajućim procesnopravnim pravilima, sud ispituje stranke, poduzima određene parnične radnje,,$^{53}$ odlučuje o prijedlozima za izvođenje dokaza, imajući pri tome u vidu materijalnopravnu osnovu i predmet spora, kao i procesnu ekonomiju postupka. ${ }^{54} \mathrm{Da}$ bi sud mogao zaključiti je li i koliko tužbeni zahtjev materijalnopravno osnovan te jesu li i koliko osnovani tuženikovi prigovori i eventualni njegovi protuzahtjevi, sud treba utvrditi (spoznati) koje su činjenice za to odlučne. Koje su činjenice relevantne u sporu koji vodi, sud će trebati prosuditi prema normama objektivnog materijalnog prava, jer upravo one određuju nastanak, promjenu i prestanak subjektivnih prava i/ili obveza, sve kao posljedicu postojanja određenih vrsta činjenica i njihovih međusobnih kombinacija. Sud prema procesnim pravilima odlučuje koje će od predloženih dokaza izvesti radi utvrđenja postojanja ili nepostojanja tvrdnji o relevantnim činjenicama koje su među strankama sporne. Koje su činjenice relevantne (sporne i nesporne), sud će morati

$51 \quad$ Istini je Michel Foucault posvetio ciklus veoma poznatih predavanja (1983./1984.) na Collegeu de France kojima je bacio novo svjetlo na stare probleme i potaknuo razmišljanja u novom smjeru. Ta predavanja, pod naslovom Le courage de la verite, Le governement de soi et des auttres II, objavio je Gallimard u Parizu 2009., a na njemački jezik prevo Jurgen Schroder pod naslovom Der Mut zur Wahrheit, Berlin, 2012., Ibid. i bilješka 59.

52 U takvom slučaju prijeti velika opasnost od pogrešne slike o činjeničnom stanju u spornom odnosu, pa je u tom pogledu na sudu profesionalna odgovornost. Uz poteškoće koje uopće opterećuju svaku spoznaju istine u sudskim postupcima postoji i sasvim praktična opasnost od prikrivanja, iskrivljavanja $\mathrm{i}$ lažnog prikazivanja činjenica, kao i manipuliranja slikom o njima. Prijeti i opasnost da sud možda neće uspjeti ispravno ocijeniti koje činjenice su sa stajališta normi materijalnog prava mjerodavne (relevantne), a i od pogreške u zaključivanju. S tim se problemima sudovi, odnosno suci u svojem radu stalno susreću i bore s više ili manje uspjeha. Nisu rijetki ni slučajevi u kojima viši sud ukida odluku suda nižeg stupnja zbog nepotpunog ili pogrešnog utvrđenog činjeničnog stanja. Time se odugovlači pravomoćno rješavanje sudskih sporova, ali to nipošto ne bi smjelo obeshrabriti odgovorna nastojanja da spoznaja bitnih činjenica bude bliska istini koliko je to u praksi najviše moguće postići. Vidi: Ibid. Bilješka br. 60 .

53 Vidi višeu: Dika, Mihajlo, Građansko procesno pravo - Parnične radnje, II dio, Narodne novine, Zagreb, 2008. i bilješku 52.

$54 \quad$ Prema odredbi čl. 10. st. 1. ZPP-a, sud je dužan postupak provesti bez odugovlačenja, u razumnom roku i sa što manje troškova te onemogućiti svaku zloporabu prava u postupku. Prema st. 2. istoga članka, sud će kazniti novčanom kaznom od 500,00 do 10.000,00 kn fizičku osobu, odnosno $2.500,00$ do $50.000,00 \mathrm{kn}$ pravnu osobu koja teže zloporabi prava koja joj pripadaju u postupku, ako ovim Zakonom nije drukčije određeno. 
prosuditi prema kriteriju koji mu za to pružaju norme objektivnog materijalnog prava. ${ }^{55}$

\subsection{Uloga materijalnog prava u odlučivanju o meritumu spora}

Nakon što sud utvrdi relevantne činjenice tj. ocijeni da su relevantne sporne činjenice dovoljno dokazane, sud je spreman donijeti svoju odluku o meritumu spora (tužbenom zahtjevu).Tu odluku treba donijeti prema odgovarajućim procesnim pravilima, primjenjujći materijalno pravo na činjenice koje je spoznao, odnosno utvrdio. ${ }^{56}$ Ta odluka odražava njegovu prosudbu o tome je li tužbeni zahtjev zaista materijalnopravno osnovan u cijelosti ili djelomično kada se uzmu u obzir osnovni materijalnopravni prigovori i protuzahtjevi tuženika. Svojom odlukom o meritumu spora (tužbenom zahtjevu) sud ne smije odrediti (usvojiti) nešto drugo, ni više od onoga što je tužitelj zahtijevao. Sud će tužbeni zahtjev usvojiti u granicama procesnopravnih mogućnosti ako, primjenom materijalnog prava na ono što je u postupku spoznao o činjenicama, dođe do zaključka da tužitelj ima ono subjektivno materijalno (građansko ili koje drugo privatno) pravo na kojem je zasnovao svoj tužbeni zahtjev. Međutim, sud neće smjeti udovoljiti tužbenom zahtjevu ako primjenom normi materijalnog prava dođe do zaključka da tužitelj nema to subjektivno materijalno pravo, odnosno neće mu udovoljiti u pogledu onoga do čega ne dosežu ovlaštenja koja mu daje njegovo subjektivno materijalno pravo. $^{57}$ Ukoliko sud donese odluku o meritumu spora (tužbenom zahtjevu), a da nije utvrdio ili je pogrešno utvrdio neku činjenicu koja je prema kriterijima koji određuju materijalnopravne norme odlučna za ocjenu materijalnopravnog elementa spornog odnosa stranaka, ta će odluka biti pobojna zbog pogrešnog ili nepotpuno utvrđenog činjeničnog stanja. ${ }^{58}$ Takvu odluku žalbeni će sud ukinuti i vratiti prvostupanjskom sudu na ponovno suđenje, ako smatra da treba, radi pravilnog utvrđivanja činjeničnog stanja, održati novu raspravu. ${ }^{59}$ Drugostupanjski sud će se pri ocjeni osnovanosti žalbe, koja je izjavljena zbog pogrešnog ili nepotpunog činjeničnog stanja, redovito poslužiti materijalnopravnim kriterijem jer, kao što je

55 Tako je i kada sud odluči da će izvesti dokaze koje stranke nisu predložile, ako je posumnjao da stranke idu za tim da raspolažu zahtjevima kojima ne mogu raspolagati jer su ti zahtjevi suprotni prisilnim propisima (čl. 7. st. 2. ZPP-a).

56 Vidi: Radolović, Aldo, „Suđenje osnovom pravičnosti, diskreciono ovlaštenje suca i slobodna ocjena dokaza“, Zbornik Pravnog fakulteta Sveučilišta u Rijeci, vol. 19, 1988., str. 1049-1063.

$57 \quad$ Ukoliko, prema kriteriju koji mu daju materijalnopravne norme, sud zaključi da tužbeni zahtjev nema svoju pravnu osnovu u subjektivnom materijalnom (građanskom ili nekom drugom privatnom) pravu koje tužitelja ovlašćuje na ono što je zatražio, da sud naloži tuženiku, zaključit će da taj tužbeni zahtjev nije materijalnopravno osnovan, pa će ga svojom odlukom odbiti (čl. 338. st. 3. ZPP-a). Gavella, N., str. 557-559 i bilješke na tim stranicama.

58 Prema odredbama čl. 353. st. 1. toč. 2. i čl. 355. ZPP-a, presuda se može pobijati i zbog pogrešno ili nepotpuno utvrđenog činjeničnog stanja, koje postoji kada je sud neku odlučnu činjenicu pogrešno utvrdio, odnosno kad je nije utvrdio.

59 Prema odredbama čl. 370. i 371. ZPP-a, kad drugostupanjski sud ukine presudu i vrati predmet na ponovno suđenje, može narediti da se nova rasprava održi pred drugim sucem pojedincem ili drugim vijećem prvostupanjskog suda. 
rečeno, ocjena o tome koje su činjenice u postojećem sporu relevantne, redovito ovisi o primijenjenim materijalnopravnim normama.

Odluka o meritumu tužbenog zahteva bit će pobojna i u slučaju kada je sud utvrdio potpuno i pravilno sve relevantne činjenice, ako je takvu odluku donio pogrešno primijenivši materijalno pravo. ${ }^{60}$ Ukoliko prvostupanjska odluka bude žalbom osnovano pobijana zbog pogrešne primjene materijalnog prava, drugostupanjski sud će je preinačiti na način da ta odluka bude primjerena onom što određuju norme materijalnog prava. ${ }^{61}$ Pri tom će postupiti prema odgovarajućim pravilima procesnog prava, ali će se pri ocjeni osnovanosti žalbe koja je izjavljena zbog pogrešne primjene materijalnog prava poslužiti kriterijima koji određuju odgovarajuće norme materijalnog prava.

Drugostupanjske sudske odluke podložne su reviziji pod pretpostavkama koje određuju pravila građanskog procesnog prava. Kada su ispunjene te pretpostavke, revizija se može podnijeti i zbog pogrešne primjene materijalnog prava. ${ }^{62}$ Ukoliko bude podnesena revizija, pa revizijski sud utvrdi, da je u drugostupanjskoj odluci materijalno pravo pogrešno primijenjeno, on će svojom presudom reviziju prihvatiti i u pravilu preinačiti pobijanu presudu. Ako ustanovi da je zbog pogrešne primjene materijalnog prava činjenično stanje nepotpuno utvrđeno, pa da zbog toga nema uvjeta za preinaku pobijane presude, prihvatit će reviziju i u cijelosti ili djelomično ukinuti presude prvostupanjskog i drugostupanjskog suda (odnosno samo presudu drugostupanjskog suda) te vratiti predmet na ponovno suđenje prvostupanjskom, odnosno drugostupanjskom sudu. ${ }^{63}$

Kada se govori o odnosu materijalnog i procesnog prava, u parnicama treba spomenuti i to da prosudba nekih na prvi pogled isključivo procesnopravnih pitanja ovisi u krajnjem slučaju o pravilima materijalnog prava. To je npr. slučaj s ocjenom je li stranka uredno zastupana ili nije, ima li stranka procesnu legitimaciju, je li izjava stranke o priznanju ili odricanju od tužbenog zahtjeva dana bez mana volje ili u bitnoj zabludi, pod utjecajem prisile ili prijevare. Cesto će i prosudba o postojanju

60 Po čl. 353. st. 1. toč. 3. i 356. ZPP-a, presuda se može pobijati i zbog pogrešne primjene materijalnog prava koja postoji kad sud nije primijenio mjerodavnu odredbu materijalnog prava ili kada takvu odredbu nije pravilno primijenio.

${ }_{61}$ Prema čl. 373. ZPP-a, drugostupanjski će sud presudom preinačiti prvostupanjsku presudu: 1) ako je prvostupanjski sud pogrešno ocijenio isprave ili posredno izvedene dokaze, a odluka je prvostupanjskog suda utemeljena isključivo na tim dokazima, 2) ako je prvostupanjski sud iz činjenica što ih je utvrdio izveo nepravilan zaključak o postojanju drugih činjenica, a na tim je (drugim) činjenicama utemeljena presuda i 3) ako smatra da je činjenično stanje u prvostupanjskoj presudi pravilno utvrđeno, ali da je prvostupanjski sud pogrešno primijenio materijalno pravo.

${ }_{62}$ Po čl. 382.a st. 1. i 2. ZPP-a, u slučajevima u kojima o žalbi protiv prvostupanjske odluke odlučuje VSRH, revizija nije dopuštena, dok u slučajevima iz st. 1. ovog članka odredba čl. 394. ovog Zakona primjenjuje se na odgovarajući način.

O podložnosti drugostupanjskih odluka reviziji zbog bitnih povreda parničnog postupka (čl. 385. st. 1. toč. 1. i 2. te st. 3. i 4. ZPP-a) ne govori se jer je pažnja primarno usmjerena na ulogu materijalnog prava i njegovu povredu u parnicama.

${ }^{63}$ Vidi odredbe čl. 395. st. 1. i i 2. te čl. 396. ZPP-a. 
ili nepostojanju ineresa ${ }^{64}$ o kojem ovise procesna prava stranaka (npr. kolektivnog interesa, pravnog interesa) ovisiti o materijalnopravnom aspektu položaja u kojem se nalazi ili se mogla naći ona stranka čiji se interes prosuđuje.

\section{UTJECAJ PARNICE NA SPORNI GRAĐANSKOPRAVNI ODNOS STRANAKA}

\subsection{O utjecaju litispendencije (parnice u tijeku)}

Time što je dostavljanjem tužbe tužitelja tuženiku njihov spor postao sudski spor, njihov se građanskopravni odnos u biti nije izmijenio. Ipak neke procesnopravne posljedice postojanja parnice (litispendencije) među njima utječe ili bi mogao utjecati na njihov građanskopravni odnos. Zbog litispendencije ne može se među istim strankama pokrenuti nova parnica u pogledu istog zahtjeva, ${ }^{65}$ što predstavlja njezin neposredni procesnopravni učinak, nego je time otvorena mogućnost određivanja privremenih mjera osiguranja (radi osiguranja novčanih i nenovčanih tražbina) i prethodnih mjera osiguranja (kad postoji sudska odluka koja nije ovršna). ${ }^{66}$ Određivanje i ukidanje mjera osiguranja obavlja se na temelju pravila procesnog prava s ciljem da se time utječe na izvršavanje subjektivnih građanskih prava osoba protiv kojih sud određuje te mjere. Kada sud odredi neku mjeru osiguranja, ona će, dokle god ne bude ukinuta, u većoj ili manjoj mjeri utjecati na subjektivna građanska prava na koja se odnosi, nekad i na materijalnopravnu poziciju trećih osoba.

\subsection{O utjecaju pravomoćnih presuda}

Nakon što sudski spor između stranaka bude okončan pravomoćnom sudskom odlukom o meritumu spora (tužbenom zahtjevu), što vrijedi i za sudsku nagodbu, to će imati mnogostruke posljedice. Glavne procesnopravne posljedice bit će u tome da više neće biti dopušteno ulaganje redovitih pravnih lijekova, ni pokretanje nove parnice među istim strankama o istom tužbenom zahtjevu te da će nakon što protekne paricijski rok biti otvoren put za pokretanje ovršnog postupka radi izvršenja

${ }_{64}$ I kada ZPP postojanje pravnog ineresa izričito ne propisuje kao pretpostavku poduzimanja neke parnične radnje (kao što je to odredio za podnošenje deklaratorne tužbe, tužbe za izdavanje platnog naloga ili reviziju), stranka treba imati takav interes, jer pravo na pravnu zaštitu pripada samo onom tko ima pravni interes koji zaslužuje da mu država (sud ili javna vlast) pruži sudsku zaštitu.

65 Prema odredbama čl. 194. ZPP-a, parnica počinje teći dostavom tužbe tuženiku. U pogledu zahtjeva koji je stranka postavila u tijeku postupka, parnica počinje teći od trenutka kad je o tom zahtjevu obaviještena protivna stranka. Dok parnica teče, ne može se u pogledu istog zahtjeva pokrenuti nova parnica među istim strankama, a ako takva parnica bude pokrenuta, sud će tužbu odbaciti. Sud će tijekom cijelog postupka po službenoj dužnosti paziti teče li već druga parnica o istom zahtjevu među istim strankama. Gavella, N., str. 560-562. i bilješke na tim stranicama.

66 Vidi više u: Tomić, Lidija, Privremene i prethodne mjere, izdanje RRIF-plus doo, Zagreb, 2010. 
onoga što takva odluka određuje. ${ }^{67}$ Pravomoćno okončanje sudskog spora među strankama mora imati i materijalnopravne posljedice, jer svrha parnice i jest da pravomoćna odluka koju sud donese o meritumu spora utječe na materijalnopravni izvansudski odnos stranaka. Taj je odnos prethodio pokretanju sudskog spora, trajao je za vrijeme parničnog postupka, a kada je taj postupak završen pravomoćnom sudskom odlukom o meritumu spora, ta bi odluka na njega trebala djelovati. Ona djeluje, jer se kaže da pravomoćna presuda za stranke predstavlja zakon, što znači da je njome otklonjena dosadašnja neizvjesnost o onome o čemu je sud pravomoćno presudio. To je postalo pravno nesporno, iako je među strankama i nadalje sporno na izvanpravnoj razini njihovih odnosa.

U pogledu djelovanja na građanskopravni odnos stranaka treba razlikovati pravni učinak pravomoćnih sudskih odluka o kondamnetornim, konstitutivnim i deklaratornim tužbenim zahtjevima. Pravomoćne sudske odluke o kondamnetornim tužbenim zahtjevima ne mijenjaju subjektivna prava, ni obveze stranaka, pa ne utječu na pravni aspekt njihovih materijalnopravnih odnosa. Međutim, utječu na ostale aspekte njihovih odnosa, socijalni, emotivni, financijski i druge, ali ne utječu neposredno i na pravni aspekt. Ovo zato, što sud svojom odlukom o kondamnetornom zahtjevu ne stvara strankama nikakvo novo pravo, odnosno obvezu, nego samo s obzirom na stanje činjenica u spornom odnosu i materijalnopravne norme koje se na njega odnose prosuđuje njihov pravni odnos. Sud je vodio postupak da bi u takvom slučaju prosudio je li tužitelju zaista pripadalo subjektivno pravo na koje je utemeljio svoj kondamnetorni tužbeni zahtjev i je li tuženik zaista s pravom istaknuo svoje materijalnopravne prigovore i protuzahtjeve, pa je prema takvoj prosudbi i presudio. Ta presuda predstavlja ovršni naslov, pa će ono što je sud njome odredio moći biti i prinudno provedeno u ovršnom postupku, ako to ne bude dobrovoljno izvršeno. Odlučivši da je tuženik dužan tužitelju izvršiti određenu činidbu, sud nije odredio ništa novo, nego je samo presudio koji je bio pravni učinak djelovanja normi materijalnog prava na materijalnopravni odnos parničnih stranaka ${ }^{68}$ Tek izvršenjem, bilo dobrovoljnim ili prisilnim, onoga što je pravomoćna sudska odluka odredila, uskladit će se odnos parničnih stranaka s materijalnim pravom. Međutim, ako je sud pogrešno prosudio da su neke činjenice pravno relevantne, premda to nisu, da su neke činjenice dokazane, a one to nisu, da su norme materijalnog prava izazvale one pravne učinke, koje nisu izazvale, pa je stoga njegova pravomoćna odluka u sudskom sporu bila pogrešna, ali je ipak postala pravomoćna, njezin materijalnopravni učinak bit će drukčiji. Na temelju takve pogrešne sudske odluke nastalo je za neku od parničnih stranaka subjektivno pravo, odnosno obveza kojih do tada nije bilo, jer joj je sud izrijekom svoje odluke dao egzistenciju. Dakle, jedino pogrešna pravomoćna kondamnetorna odluka stvara subjektivno materijalno pravo, odnosno obveze među strankama, čime itekako utječe na njihov međusobni odnos.

${ }_{67}$ O djelovanju pravomoćnosti sudskih odluka Vidi u: Triva - Dika, o. c., paragraf 145, 146, 147 i 148 , str. 626-657.

68 Pravomoćnom sudskom odlukom ne nastupa obnova (novacija) ičijih obveza, nego bi se moglo reći samo sanacija materijalnopravnog odnosa među strankama. 
Svrha parničnog postupka koji se vodi po konstitutivnom tužbenom zahtjevu jest uređenje odnosa među strankama sudskom odlukom, koja će nakon što postane pravomoćna utjecati, i to u pravilu neposredno, na materijalnopravni odnos parničnih stranaka. Ako je na temelju nekog svojeg potestativnog prava (subjektivnog materijalnog prava) koje svojeg nositelja ovlašćuje da ishodi odluku suda kojom će proizvesti određeni pravni učinak prema drugoj osobi (osnivanje, promjenu ili prestanak pravnog odnosa s njom) tužitelj od suda zahtijevao odrediti nastupanje nekog pravnog učinka, pravomoćna sudska odluka kojom bi on taj zahtjev usvojio imala bi odgovarajući učinak na pravni odnos tužitelja i tuženika ${ }^{69}$

Deklaratorne sudske odluke nemaju neposredni materijalnopravni, nego procesnopravni učinak.

Kao što je već spomenuto, neposredno djelovanje tužbe na utvrđenje zapravo je procesnopravnog karaktera. Ono što sud pravomoćno utvrdi svojom odlukom redovito je namijenjeno tome da tužitelju posluži u nekom drugom sudskom ili kojem drugom postupku u kojem više neće moći biti osporavano. Deklaratorne sudske odluke ne proizvode nikakve neposredne materijlnopravne učinke na odnose stranaka, ${ }^{70}$ ali ih se donosi da bi se utvrdio materijalnopravni učinak koji je već nastupio ili da se pripremi procesnopravni teren za vođenje daljnjih postupaka. ${ }^{71}$

\section{ZAKLJUČNA RAZMATRANJA}

Materijalno i procesno građansko pravo imaju mnoge višeslojne i neraskidive funkcionalne sveze bez obzira na njihovu različitu pravnu prirodu. Zbog toga sudski sporovi imaju materijalnopravne i procesnopravne sastavnice. Procesno pravo im daje dinamiku, a materijalno pravo društvenu svrhu. Te se funkcije međusobno isprepliću u svrhu donošenja sudske pravomoćne odluke o meritumu.

69 Npr. ako je tužitelj na temelju svojeg prava na poništaj ili na razvod braka ishodio pravomoću presudu kojom sud poništava brak s tuženom osobom, odnosno razvodi ga, brak je prestao u trenutku pravomoćnosti te presude (čl. 47. st. 2. Obiteljskog zakona, NN 103/15, koji je na snazi od 1. studenoga 2015. godine).

Od toga treba razlikovati situaciju u kojoj je tužiteljevo potestativno pravo već djelovalo po sili normi materijalnog prava (npr. kod ništetnosti ugovora). U takvoj će situaciji sudska odluka samo konstatirati učinak koji je u materijalnopravnom odnosu stranaka već nastupio. Ako je materijalnopravni učinak na pravni odnos tužitelja i tuženika već nastupio, samim očitovanjem volje tužitelja (npr. primanjem izjave o prihvaćanju ponude, prema čl. 262. ZOO-a - NN 35/05, 41/08, 125/11) ili pak na temelju zakona (npr. ako je kupac robe s nedostatkom dao prodavatelju naknadni primjereni rok za ispunjenje ugovora, a taj nije ni u tom roku ispunio ugovor (prema čl. 413. st. 2. ZOO-a), taj učinak na pravni odnos tužitelja tuženika može biti predmetom sudskog spora, ali odluka koju će sud donijeti neće biti konstitutivne, nego deklaratorne prirode.

70 O tome da podnošenje ili nepodnošenje nekih vrsta deklaratronih tužbi ipak ima parakonstitutivni učinak upozorio je Mihajlo Dika, o. c., str. 255-256, o čemu je već ranije bilo govora.

${ }_{71}$ Ako je deklaratorna sudska odluka pogrešna, ona može izazvati materijalnopravne učinke, kao npr. u slučaju da je pogrešno utvrđeno očinstvo ili majčinstvo djeteta. Ako je materijalnopravni učinak na pravni odnos stranaka već nastupio samim očitovanjem volje, taj učinak može biti predmetom sudskog spora, ali odluka neće biti konstitutivne, nego deklaratorne naravi. 
Sudski spor se njačešće vodi oko nekih subjektivnih prava i/ili obveza, odnosno privatnopravnog statusa stranaka, a ne oko činjenica, bez obzira na to što su često i činjenice sporne. Zato se o njima raspravlja te nastoji spoznati i dokazati relevantno (odlučno) činjenično stanje, što je nužno. Spoznaja činjenica o pravnom odnosu stranaka otkriva nam postojanje i pravnu sudbinu subjektivnih materijalnih prava i/ili obveza stranaka. Ovo zato što norme materijalnog prava vežu nastajanje, promjenu i njihov prestanak pod uvjetom nastupanja određenih vrsta činjenica. Stoga prof. Dika osnovano upozorava da osnovanost tužbenog zahtjeva kao prijedloga izreke presude određenog sadržaja nije moguće ocijeniti izravno na temelju iznesenih činjenica, koje će biti utvrđivane u postupku. Da bi sud mogao donijeti odluku o tome, on mora na utvrđeno činjenično stanje primijeniti materijalno pravo i nakon doga doći do zaključka jesu li u konkretnom sporu ispunjeni uvjeti za prihvaćanje tužbenog zahtjeva. Prof. Gavella dodaje da će, pored navedenoga, to biti i zaključak o subjektivnim pravima, odnosno obvezama ili pravnom statusu parničnih stranaka.

Iz normi materijalnog prava nesumnjivo za pojedince (građane) proizlaze subjektivna građanska (privatna) prava. Sporovi koji nastanu među njima u svezi s njihovim sudjelovanjem u pravnim odnosima jesu sporovi o njihovim subjektivnim pravima $\mathrm{i} / \mathrm{ili}$ obvezama, odnosno o pravnom statusom kao naličju tih i takvih odnosa. Tek kada netko od sudionika u sporu podnese tužbu sudu, time taj spor dobiva kvalifikaciju sudskog spora te tada subjektivno pravo ili pravni status koji navodno tužitelja pripada i koji nastoji sudskim putem ostvariti ili zaštititi u odnosu prema tuženiku postaje materijalnopravna osnova tog spora, odnosno parnice. Za vođenje i tijek parničnog postupka najvažnija je jasna spoznaja na kojem to svojem navodnom subjektivnom materijalnom pravu ili pravnom statusu tužitelj zasniva svoj tužbeni zahtjev. Takva je spoznaja potrebna svim sudionicima u postupku kako bi svoje djelovanje usmjerili prema dokazivanju i utvrđivanju onih činjenica koje su relevantne, odnosno pravno odlučne za rješenje spora. Ako sud nema jasnu spoznaju o tome, nalazit će se u nezavidnoj situaciji u kojoj može samo nagađati o materijalnopravnoj osnovi spora. Nedvojbeno je da sud treba znati pravo (iura novit curia), ali treba znati i koje materijalno pravne norme primijeniti u konkretnom sporu i glede odluke o njegovu meritumu. ${ }^{72}$ Bilo bi poželjno da to znaju i stranke radi savjesnog korištenja svojim subjektivnim pravima.

Kako sudski spor ima materijalnopravne i procesnopravne sastavnice, nužno je u ocjeni njegova identiteta uzeti u obzir i njegovu materijalnopravnu osnovu, jer te njegove sastavnice određuju njegov identitet koji je vrlo značajan s obzirom na probleme objektivne kumulacije tužbenih zahtjeva, ${ }^{73}$ preinake tužbe te djelovanja litispendencije i pravomoćnosti sudske odluke. Da bi se moglo zaključiti da je jedan

72 Ako o materijalnopravnoj osnovi tužbenog zahtjeva sud nije siguran, morat će utvrđivati širi krug činjenica od onih koje su relevantne, te udovoljiti procesnim zahtjevima stranaka koji nisu potrebni itd. Kad viši sud bude odlučivao o žalbi, možda dođe do zaključka da je potrebno proširiti krug činjenica koje treba utvrditi i/ili da je potrebno udovoljiti još nekim procesnim zahtjevima i prijedlozima stranaka, koje prvostupanjski sud nije prihvatio.

73 Neuzimanje u obzir materijalnopravne osnove spora ima za posljedicu sudsku praksu koja negira dopuštenost kumuliranja naknade štete i osigurnine iz ugovora o osiguranju od posljedica nesretnog slučaja. O tome više vidiu: Belanić, Loris, „Kumulacija zahtjeva za naknadu štete i osigurnine iz ugovora 
spor identičan $\mathrm{s}$ drugim, jer se već takav među strankama vodi ili je već pravomoćno okončan, nije dovoljno da oba spora budu začeta među istim strankama, da su relevantne činjenice iste i da u objema tužitelj postavlja isti tužbeni zahtjev, nego je pored toga nužno voditi računa i o njegovoj materijalnopravnoj osnovi. Zato prof. Gavella pravilno zaključuje da se, ako se on ne uzme u obzir, može nekada zaključiti kako je jednako ono što ipak nije jednako, a tada mogu proisteći procesnopravne posljedice koje će se negativno odraziti na subjektivna prava stranaka, na procesnopravnom statusu i obvezama drugih osoba.

\section{SIGNIFICANCE OF SUBSTANTIVE CONSTITUENTS IN COURT DISPUTE}

Legal entities with access to legal norms are given powers, duties and responsibilities or ban certain kinds of behaviour when the hypothesis of predicted facts from these legal norms occur. Subjective rights and responsibilities of certain behaviours find legal support or basis in substantive legal norms of civil public and private law.

In order for certain legal civil relations with subjective rights and responsibilities to occur, it is necessary for the creation of all the facts that the substantive norm demands as a presumption for its creation, change or cessation.

In the causal complexity of creation or change of every legal civil relation, there is always a legal and factual base. Therefore, the establishment of the existence of concrete subjective civil rights and duties must assume proof of its legal and factual basis.

Deciding on the merit of a dispute, that is, how founded or not founded the lawsuit is, has proven to be the most difficult task for all its participants. This is because each person must correctly and legally evaluate the influence of all legal factors, that is constituents on the results of the court dispute. These constituents, or factors in this paper are analysed from a substantive civil law aspect with emphasis on its role in the treatment of the civil law and court dispute, legal foundation of the lawsuit, substantive law and factual basis of the dispute and its role in disputable civil law relations of the parties.

Key words: civil law dispute, court dispute, law suit, legal basis, factual basis, subjective right

o osiguranju od posljedica nesretnog slučaja“, Informator, Novi informator d.o.o., Zagreb, br. 5953/2011, str.11-12, i br. 5954/2011, str. 5-6. 